Boni Bryan, Ahmad Junaidi: Pengaruh Media Sosial Instagram \#Covid-19 terhadap Tingkat Kepercayaan Masyarakat Milenial di Jakarta

\title{
Pengaruh Media Sosial Instagram \#Covid-19 terhadap Tingkat Kepercayaan Masyarakat Milenial di Jakarta
}

\author{
Boni Bryan, Ahmad Junaidi \\ boni.915170178@stu.untar.ac.id,ahmadd@fikom.untar.ac.id
}

Fakultas Ilmu Komunikasi Universitas Tarumanagara

\begin{abstract}
The COVID-19 pandemic has plagued all parts of the world, including Indonesia. Since its first appearance in China, the spread of the COVID-19 virus has been very fast and the number of infected people has grown very significantly and rapidly. Various information related to COVID-19 is spread on social media, especially Instagram. Some are true, some are misleading. Some believe in fact-based information and data, but others don't. There are those who believe in hoaxes, but there are also those who don't. Therefore, it is very important to measure the level of public trust based on what they see and what they perceive. Here the writer uses communication theory, communication media theory, factors that influence trust, and mass communication theory as the theoretical basis. This study uses millennial Instagram users in Jakarta as the object of research. So that when viewed in terms of variables, there are 2 variables, namely the Instagram \# COVID-19 variable and the level of trust of the millennial community in Jakarta. The approach of this research is quantitative with a survey method which is carried out by distributing questionnaires in the form of google form to respondents who meet the requirements. Data processing uses the help of SPSS Version 20, from the respondent's data tested valid and reliable. The data analysis technique used regression analysis and the results proved that variable $X$ had an effect on variable $Y$, because the significance value was 0 . According to Sahid Raharjo (2018) if the significance value was $<0.05$, it was certain that there was an influence of variable $x$ on variable Y. That means Instagram \# COVID-19 has an influence on the level of trust of millennials in Jakarta.
\end{abstract}

Keywords: covid-19, instagram, media, millennial

\begin{abstract}
Abstrak
Pandemi COVID-19 telah mewabah di seluruh belahan dunia, tak terkecuali Indonesia. Sejak kemunculan pertamanya di negara Tiongkok, penyebaran virus COVID-19 sangat cepat dan angka orang yang tertular pun bertumbuh dengan sangat signifikan dan pesat. Berbagai informasi terkait COVID-19 tersebar di media sosial khususnya Instagram. Ada beberapa yang benar, ada juga menyesatkan. Ada yang percaya pada informasi yang berbasis fakta dan data, namun ada juga yang tidak. Ada yang percaya pada hoax, tetapi ada juga yang tidak percaya. Oleh karena itu, penting sekali untuk mengukur tingkat kepercayaan masyarakat berdasarkan apa yang mereka lihat dan yang mereka serap. Disini penulis menggunakan sejumlah teori dan konsep mulai dari komunikasi, media sosial, faktor-faktor yang mempengaruhi kepercayaan, dan komunikasi massa. Penelitian ini menggunakan pengguna Instagram masyarakat millennial di Jakarta sebagai populasi sehingga jika dilihat dari segi variabel terdapat dua variabel yaitu variabel Instagram \#COVID-19 dan variabel tingkat kepercayaan masyarakat millennial di Jakarta. Pendekatan penelitian ini adalah kuantitatif dengan metode survei yang dilakukan melalui penyebaran kuesioner dalam bentuk google form kepada responden yang memenuhi syarat. Pengolahan data menggunakan bantuan SPSS Versi 20, dari data responden teruji valid, dan reliabel. Teknik analisis data menggunakan analisis regresi dan hasilnya terbukti bahwa variabel $\mathrm{X}$ berpengaruh terhadap
\end{abstract}


variabel Y, karena nilai signifikansinya 0. Menurut Sahid Raharjo (2018) jika nilai signifikansi $<0,05$ maka bisa dipastikan bahwa terdapat pengaruh dari variabel $\mathrm{x}$ terhadap variabel Y. Itu artinya Instagram \#COVID-19 memiliki pengaruh terhadap tingkat kepercayaan milenial di Jakarta.

Kata Kunci: covid-19, instagram, media, milenial

\section{Pendahuluan}

Saat ini dunia sedang dilanda pandemi virus corona. Virus corona menurut Direktorat Jenderal Pencegahan dan Pengendalian Penyakit (2020) adalah keluarga besar virus yang menyebabkan penyakit mulai dari gejala ringan hingga gejala berat. Asal usul virus ini juga belum diketahui, yang pasti virus ini pertama kali ditemukan di Wuhan, Tiongkok. Direktorat Jenderal Pencegahan dan Pengendalian Penyakit juga menambahkan Coronavirus Diseases 2019 (COVID19) ditetapkan sebagai penyakit jenis baru yang belum pernah diidentifikasi sebelumnya pada manusia (Direktorat Jenderal Pencegahan dan Pengendalian Penyakit, 2020).

Pertanda dan gejala awal saat terpapar virus COVID-19 antara lain gangguan pernapasan akut seperti batuk-batuk, demam, dan sesak napas. Rata-rata masa inkubasinya adalah 5- 6 hari dengan masa inkubasi terpanjangnya adalah 14 hari. Tanggal 30 Januari 2020 WHO menetapkan virus COVID-19 sebagai pandemi dan kedaruratan kesehatan masyarakat yang mengguncang dunia. Tanggal 2 Maret 2020, Indonesia melaporkan kasus pertama virus COVID-19. Sebanyak 2 orang terjangkit virus tersebut. Sejak saat itu angkanya pun terus bertambah. (Yurianto, Wibowo, 2020).

Media sosial adalah media yang digunakan oleh individu agar menjadi sosial, ataupun menjadi sosial secara daring dengan cara berbagi isi, berita, foto dan lainlain dengan orang lain. (Taprial \& Kanwar, 2012). Media sosial sendiri memiliki keterikatan dengan komunikasi massa, karena objek dari media sosial adalah khalayak banyak, yang mana tujuannya agar banyak orang bisa menerima informasi ataupun pesan yang dimaksud.

Menurut Jay Black dan Frederick C, komunikasi massa adalah sebuah proses dimana pesan-pesan yang diproduksi secara massal/tidak sedikit itu disebarkan kepada massa penerima pesan yang luas, anonim, dan heterogen (Nurudin, 2010). Pengguna media sosial sendiri didominasi oleh kalangan millenial, entah apa alasannya, namun media sosial cenderung dinilai lebih modern dan memiliki fitur yang cocok dengan millenial ketimbang orang tua. Generasi milenial menurut Yuswohady dalam artikel Milennial Trends (Millennial Generation) adalah generasi yang lahir dalam rentang waktu awal tahun 1980 hingga tahun 2000. Generasi ini sering disebut juga sebagai Gen-Y, Net Generation, Generation WE, Boomerang Generation, Peter Pan Generation, dll. Generasi ini disebut generasi milenial karena mereka adalah generasi yang hidup di pergantian milenium.

Di waktu yang bersamaan, pada era inilah teknologi digital mulai merasuk ke segala sendi kehidupan. Kartikoyono (Kartikoyono, 2019) menyebutkan bahwa generasi millenial adalah tech savvy, tech savvy sendiri artinya adalah penggemar teknologi. Oleh karena itu, generasi millenial selalu melihat informasi di internet atau media sosial, untuk mencari suatu kebenaran atau fakta. Selain itu, pandangan atau pendapat orang lain di media online sangat menentukan pola pikir mereka mulai dari tergiringnya opini mereka hingga hal-hal lain yang lebih serius dalam kehidupan (Harsanto, 2019). 
Boni Bryan, Ahmad Junaidi: Pengaruh Media Sosial Instagram \#Covid-19 terhadap Tingkat Kepercayaan Masyarakat Milenial di Jakarta

Penelitian ini akan fokus pada media sosial Instagram. Instagram sendiri adalah media sosial terbesar di Indonesia. Instagram cukup populer di kalangan anak muda Indonesia karena fiturnya terkesan tidak kuno dan sangat cocok untuk anak millenial, sehingga tidak heran berbagai aktivitas seperti penyampaian informasi (terlepas dari hoax atau tidak) berkehimpunan di wadah komunikasi digital tersebut. Beberapa pengguna Instagram bergerak dengan menyebar dan membagikan informasi, terlepas dari apakah itu hoax atau benar.

Masyarakat berperan sebagai receiver. Peneliti ingin mengetahui seberapa besar pengaruh Instagram \#COVID-19 terhadap tingkat kepercayaan masyarakat millenial di Jakarta. Hal ini cukup menarik bagi peneliti, karena informasi pandemi COVID-19 sebagian besar berasal dari platform media sosial terutama Instagram, tanpa adanya media sosial Instagram apakah penyampaian informasi tetap efektif?

\section{Metode Penelitian}

Pada penelitian ini, penulis menggunakan metode kuantitatif dan suvei sebagai teknik pengumpulan data. Menurut Bagja Waluya (2010), metode survei merupakan metode angket atau metode yang biasa kita sebut sebagai kuisioner, biasanya juga didefinisikan sebagai formulir yang berisi serangkaian pertanyaan yang telah disusun secara sistematis lalu dikirimkan kepada responden untuk mendapatkan tanggapan. Penulis menggunakan instrumen ini karena dirasa cocok dan efektif. Selain itu metode ini wajib dilakukan agar bisa melihat sudut pandang yang berbeda. Peneliti memilih menggunakan kuesioner yang telah disusun secara teratur dalam bentuk google form dan disebarkan kepada responden yang memenuhi syarat untuk dijawab.

Populasi pada penelitian ini yaitu masyarakat millennial pengguna Instagram di Jakarta yang berjumlah kurang lebih 2,5 juta orang. Dalam menentukan banyaknya responden yang diperlukan pada penelitian ini, penulis menggunakan rumus Slovin dengan persentase kesalahan 10\%, hasilnya yaitu sebanyak 100 responden sebagai sampel yang mewakili populasi. Peneliti menentukan 100 responden yang berhak menjadi sampel melalui teknik purposive sampling. Menurut Sugiyono (2017), purposive sampling merupakan teknik pengambilan sampel berdasarkan pertimbangan kriteria khusus yang ditentukan peneliti. Pertimbangan yang penulis maksud adalah pengguna Instagram domisili Jakarta yang berusia 20 sampai dengan 40 tahun di tahun 2020 sesuai dengan definisi millennials yang sebenarnya.

Teknik pengolahan data menggunakan program Statistical Product and Service Solutions (SPSS) versi 20. Sebelum melakukan analisis data, peneliti menguji keabsahan data yang telah dikumpulkan melalui uji validitas dan uji reliabilitas. Kemudian, memasuki tahap teknik analisis data yang digunakan peneliti untuk menjawab pertanyaan peneliti ataupun membuktikan hipotesis yaitu dengan Uji Regresi Linear Sederhana.

\section{Hasil Temuan dan Diskusi}

1. Uji Validitas

Tabel 1. Hasil Uji Validitas

\begin{tabular}{|c|c|c|c|c|}
\hline Var & Butir Ind & R hitung & R Tabel & Keterangan \\
\hline Medic & sosial (Instagram & 0.739 & 0.195 & Valid \\
\hline
\end{tabular}




\begin{tabular}{|c|c|c|c|c|}
\hline \multirow{10}{*}{$\begin{array}{c}\text { Sosial } \\
\text { (Instagram) } \\
\text { \#COVID-19 } \\
\text { (X) }\end{array}$} & \#COVID-19 1 & & & \\
\hline & $\begin{array}{lll}\text { Media sosial (Instagram) } \\
\text { \#COVID-19 } 2\end{array}$ & 0.651 & 0.195 & Valid \\
\hline & $\begin{array}{l}\text { Media sosial (Instagram) } \\
\text { \#COVID-193 }\end{array}$ & 0.712 & 0.195 & Valid \\
\hline & $\begin{array}{lll}\text { Media } & \text { sosial } & \text { (Instagram) } \\
\text { \#COVID-19 } 4 & \end{array}$ & 0.763 & 0.195 & Valid \\
\hline & $\begin{array}{lrl}\text { Media sosial (Instagram) } \\
\text { \#COVID-19 } 5\end{array}$ & 0.650 & 0.195 & Valid \\
\hline & $\begin{array}{lll}\text { Media sosial } & \text { (Instagram) } \\
\text { \#COVID-19 } 6 & \end{array}$ & 0.645 & 0.195 & Valid \\
\hline & $\begin{array}{lr}\text { Media } & \text { sosial } \\
\text { \#COVID-19 } 7\end{array}$ & 0.729 & 0.195 & Valid \\
\hline & $\begin{array}{lrl}\text { Media sosial } & \text { (Instagram) } \\
\text { \#COVID-19 } 8 & \end{array}$ & 0.760 & 0.195 & Valid \\
\hline & $\begin{array}{l}\text { Media sosial (Instagram) } \\
\text { \#COVID-19 } 9\end{array}$ & 0.629 & 0.195 & Valid \\
\hline & $\begin{array}{l}\text { Media sosial (Instagram) } \\
\text { \#COVID-19 } 10\end{array}$ & 0.621 & 0.195 & Valid \\
\hline \multirow{4}{*}{$\begin{array}{l}\text { Tingkat } \\
\text { Kepercayaan } \\
\text { Masyarakat } \\
\text { Millennials } \\
\text { Jakarta (Y) }\end{array}$} & $\begin{array}{lr}\text { Tingkat } & \text { Kepercayaan } \\
\text { Masyarakat } & \text { Millennials } \\
\text { Jakarta 1 } & \\
\end{array}$ & 0.886 & 0.195 & Valid \\
\hline & $\begin{array}{lr}\text { Tingkat } & \text { Kepercayaan } \\
\text { Masyarakat } & \text { Millennials } \\
\text { Jakarta 2 } & \\
\end{array}$ & 0.821 & 0.195 & Valid \\
\hline & $\begin{array}{lr}\text { Tingkat } & \text { Kepercayaan } \\
\text { Masyarakat } & \text { Millennials } \\
\text { Jakarta 3 } & \\
\end{array}$ & 0.855 & 0.195 & Valid \\
\hline & $\begin{array}{lr}\text { Tingkat } & \text { Kepercayaan } \\
\text { Masyarakat } & \text { Millennials } \\
\text { Jakarta } 4 & \\
\end{array}$ & 0.791 & 0.195 & Valid \\
\hline
\end{tabular}

Sumber: Hasil Olah Data Peneliti

Berdasarkan hasil uji validitas, dapat disimpulkan bahwa sebanyak 10 butir pernyataan variabel media sosial (instagram) \#COVID-19 (X) dan 4 butir pernyataan tingkat kepercayaan masyarakat $(\mathrm{Y})$ memiliki nilai $r$ hitung $>r$ tabel yang berarti total 14 pernyataan kedua variabel tersebut dinyatakan valid.

2. Uji Reliabilitas

Tabel 2. Hasil Uji Reliabilitas

\begin{tabular}{|l|l|l|l|}
\hline Variabel & $\begin{array}{l}\text { Jumlah } \\
\text { Pertanyaan }\end{array}$ & $\begin{array}{l}\text { Cronbach } \\
\text { Alpha }\end{array}$ & Reliabilitas \\
\hline $\begin{array}{l}\text { Media Sosial (Instagram) } \\
\text { COVID-19 }\end{array}$ & 10 & 0.869 & Reliabel \\
\hline $\begin{array}{l}\text { Tingkat Kepercayaan } \\
\text { Masyarakat Millennials } \\
\text { Jakarta }\end{array}$ & 4 & 0.858 & Reliabel \\
\hline
\end{tabular}

Sumber: Hasil Olah Data Peneliti 
Boni Bryan, Ahmad Junaidi: Pengaruh Media Sosial Instagram \#Covid-19 terhadap Tingkat Kepercayaan Masyarakat Milenial di Jakarta

Berdasarkan perhitungan pada Tabel 2, dapat disimpulkan bahwa seluruh pernyataan dalam kuesioner dinyatakan reliabel karena memiliki nilai Cronbach's Alpha $>0.6$

3. Analisis Regresi

Tabel 3. Hasil Uji Regresi Linear Sederhana

\section{Coefficients $^{\mathrm{a}}$}

Unstandardized

Coefficients

\begin{tabular}{llrrrrrr} 
Model & \multicolumn{2}{c}{ B } & Std. Error & Beta & \multicolumn{1}{c}{ t } & \multicolumn{1}{c}{ Sig. } \\
\hline 1 & (Constant) &,- 180 & 1,620 & &,- 111 &, 912 \\
\cline { 2 - 7 } &, 372 &, 038 &, 701 & 9,732 &, 000 \\
\hline
\end{tabular}

a. Dependent Variable: tkm

Sumber: Hasil Olah Data Peneliti

Menurut Sugiyono (2017), uji regresi linear sederhana digunakan untuk mengetahui hubungan antara variabel independen $(\mathrm{X})$ terhadap variabel dependen (Y). Persamaan regresi linear sederhana dirumuskan sebagai $\mathrm{Y}=\mathrm{a}+\mathrm{bX}$. Maka, berdasarkan tabel di atas, diketahui nilai constant (a) sebesar -0.180 sedangkan nilai dari variabel X (media sosial (Instagram) \#COVID-19) yaitu 0.372. Sehingga, persamaan regresinya yaitu $Y=-0.180+0.372 X$. Terlebih lagi Sahid Raharjo (2018) mengatakan jika nilai signifikansi $<0,05$ maka bisa dipastikan bahwa terdapat pengaruh dari variabel $\mathrm{X}$ terhadap variabel $\mathrm{Y}$. Pada tabel diatas nilai signifikansinya 0 , artinya nilai signifikansi $<0,05$. Dengan kata lain, variabel $\mathrm{X}$ beperpengaruh terhadap variabel Y.

\section{Simpulan}

Berdasarkan hasil penelitian yang telah diperoleh dengan tujuan mengetahui apakah ada pengaruh media sosial Instagram \#COVID-19 terhadap tingkat kepercayaan masyarakat millennial di Jakarta, peneliti mengambil kesimpulan bahwa terdapat pengaruh media sosial Instagram \#COVID-19 terhadap tingkat kepercayaan masyarakat millennials di Jakarta. Hal ini ditinjau melalui hasil analisis regresi yang sudah peneliti lakukan. Yaitu sebesar 0,000 nilai signifikansi dari X. Itu artinya jika nilai signifikansi $<0,05$ variabel $\mathrm{X}$ berpengaruh terhadap variabel $\mathrm{Y}$, dengan kesimpulan Hol ditolak sementara Hal diterima.

\section{Ucapan Terima Kasih}

Penulis ingin menyampaikan terima kasih kepada seluruh pihak yang telah mendukung dan membantu penulis dalam penyelesaian penelitian ini, khususnya kepada Fakultas Ilmu Komunikasi Universitas Tarumanagara.

\section{Daftar Pustaka}

Deloitte Indonesia Perspectives. (2020). Generasi Milenial Dalam Industri 4.0 : Berkah Bagi Sumber Daya Manusia Indonesia Atau Ancaman, hal. 25-26. 
Direktorat Jenderal Pencegahan dan Pengendalian Penyakit. (2020). Pedoman Pencegahan Dan Pengendalian CoronaVirus Disease (COVID-19). Jakarta: Kementerian Kesehatan Republik Indonesia.

Kanwar, P. \& Taprial, V. (2012). Understanding Social Media. London: Ventus Publishing.

Nurudin. (2010). Pengantar Komunikasi Massa. Jakarta: Raja Grafindo Persada.

Raharjo, S. (2020). Uji Regresi Linear Sederhana dengan SPSS Sangat Detail. Jakarta Timur, DKI Jakarta, Indonesia.

Sugiyono. (2017). Metode Penelitian Kebijakan: Pendekatan Kuantitatif, Kualitatif, Kombinasi,R\&D Dan Penelitian Evaluasi. Bandung: Alfabeta.

Waluya, B. (2010). Sosiologi : Menyelami Fenomena Sosial Di Mayarakat. Bandung: Setia Purna Inves.

Yuswohady. (2016). Millenials Kills Everything. Jakarta: PT. Gramedia Pustaka Utama. 